\title{
On the Floras of Certain Islets outlying from Stewart Island (New Zealand).
}

\author{
BY \\ J. C. WILLIS, M.A., Sc.D., F.R.S., \\ Eurobean Correspondent, Botanic Gardens, Rio de Janeiro.
}

With one Map in the Text.

$\mathrm{N}^{\mathrm{N}}$ interesting little paper by Poppelwell on the flora of Long Island, which is separated by one and a half miles of water from the south-west of Stewart Island, has called my attention to further papers on the islets which outlie from Stewart, especially the Breakseas and Solanders, the former close to the east coast of Stewart, the latter about thirty-five miles from the north-west coast and rather nearer to the South Island of New Zealand. These papers ${ }^{1}$ are best considered together; they illustrate very clearly the extraordinary applicability of age and area to the New Zealand flora, and suggest a way in which it may be applied even to the flora of Great Britain, where the effects of man's occupation are

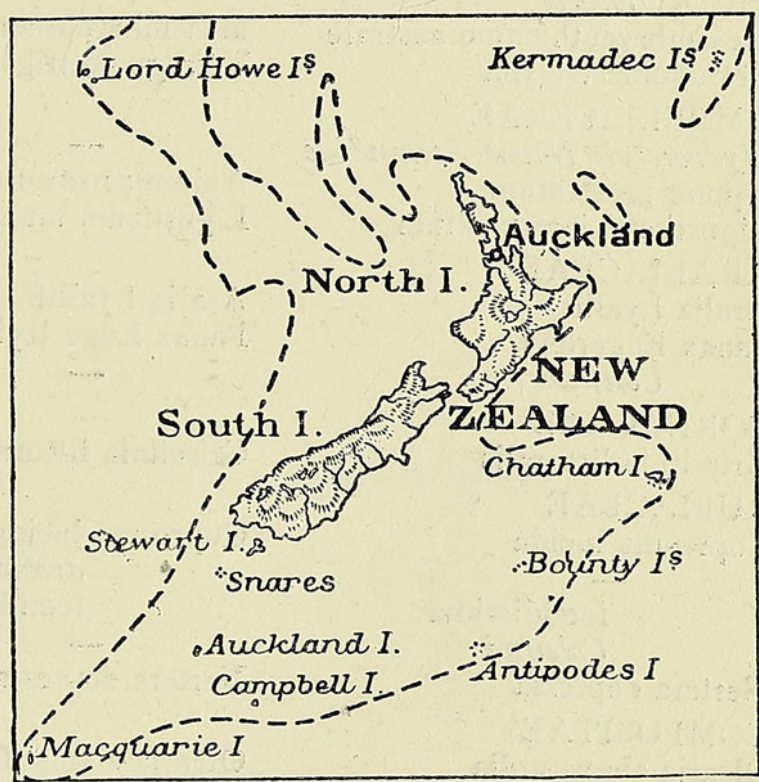

New Zealand and outlying islands. The dotted line is the $\mathrm{I}, 000$ fathom limit. now so predominant.

The simplest way of dealing with the matter will probably be to first of all arrange these little floras in parallel columns, classified for convenience as in Cheeseman's 'Flora'.

1 Poppelwell : Notes of a Botanical Excursion to Long Island. Trans. and Proc. N.Z. Inst., xlix, 191 7 , p. 167 .

Notes on the Plant Covering of the Breaksea Islands, 1.c., xlviii, I9I6, p. 246.

Cockayne: On a Collection of Plants from the Solanders, l.c., xli, 1909, p. 404.

[Annals of Botany, Vol. XXXIII. No. CXXXII. October, 1919.] 


\section{TABLE I.}

\section{Species in italics are peculiar to one island.}

\section{Long Island.}

CRUCIFERAE

Cardamine heterophylla

PITTOSPORACEAE

ROSACEAE

\section{SAXIFRAGACEAE}

Weinmannia racemosa

CRASSULACEAE

Tillaea moschata

DROSERACEAE

Drosera spathulata

MYRTACEAE

Leptospermum scoparium

Metrosideros lucida

ONAGRACEAE

\section{FICOIDEAE}

Mesembryanthemum australe

Tetragonia trigyna

UMBELLIFERAE

Hydrocotyle Novae-Zeelandiae

Apium prostratum

Ligusticum intermedium

\section{ARALIACEAE \\ Aralia Lyallii \\ Panax Edgerleyi \\ Colensoi}

CORNACEAE

Griselinia littoralis

RUBIACEAE

Coprosma lucida

foetidissima Colensoi

Nertera depressa

COMPOSITAE

Olearia angustifolia

Colensoi

arborescens

Celmisia longifolia

Senecio bellidioides

$$
\text { rotundifolius }
$$

STYLIDIACEAE

Donatia Novae-Zeelandiae

GOODENIACEAE

ERICACEAE

Gaultheria antipoda
Breakseas.

Solanders.

Cardamine heterophylla

Lepidium oleraceum

Pitlosporum Colensoi

Rubus australis

Tillaea moschata

Drosera spathulata

Leptospermum scoparium

Metrosideros lucida

Fuchsia excorticata

Mesembryanthemum australe

Tetragonia trigyna

Apium prostratum

Ligusticum intermedium

Aralia Lyallii

Panax Edgerleyi

Griselinia littoralis

Coprosma lucida areolata foetidissina

Nertera depressa

Olearia angustifolia

Colensoi

Traillii

arborescens

Cotula coronopifolia (probably introduced)

Senecio lautus

rotundifolius

Sonchus littoralis

Oreostylidium subulatum

Selliera radicans
Tillaea moschata

Mesemb. austr.

Apium prostratum Ligust. intermedium

Aralia Lyallii

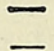

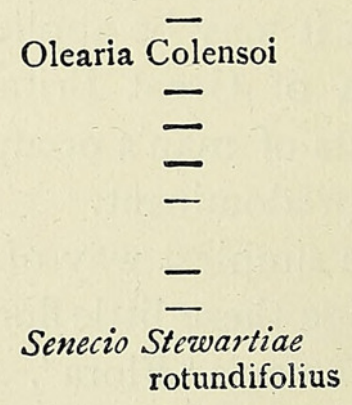

otundifolius 
TABLE I (continued).

Long Island.

EPACRIDACEAE

Pentachondra pumila

Styphelia acerosa empetrifolia

Dracophyllum longifolium

MYRSINACEAE

Suttonia chathamica

\section{GENTIANACEAE}

BORAGINACEAE

Myosotis albida

SCROPHULARIACEAE

Veronica elliptica buxifolia

PLANTAGINACEAE

URTICACEAE

Urtica australis

ORCHIDACEAE

LILIACEAE

Phormium tenax Cookianum

Enargea parviflora

Astelia linearis nervosa

JUNCAC.EAE

Luzula campestris

RESTIONACEAE

CYPERACEAE

Scirpus aucklandicus nodosus

Gahnia procera

Oreobolus pectinatus

Carex lucida strictus

$$
\text { trifida }
$$

GRAMINEAE

Hierochloe redolens

Microlaena avenacea

Poa foliosa

Astoni

CONIFERAE

Podocarpus ferrugineus

Dacrydium intermedium

HYMENOPHYLI,ACEAE Hymenophyllum rufescens

CYATHEACEAE

Dicksonia squarrosa Hemitelia Smithii
Breakseas.

Solanders.

Pentachondra pumila

Styphelia acerosa

Dracophyllum longifolium

Rapanea Urvillei

Gentiana saxosa

Myosotis albida

Veronica elliptica

Plantago Raoulii

Thelymitra longiflora uniflora

Microtis unifolia

Prasophyllum Colensoi

Pterostylis Banksii

australis

Caladenia bifolia

Phormium tenax

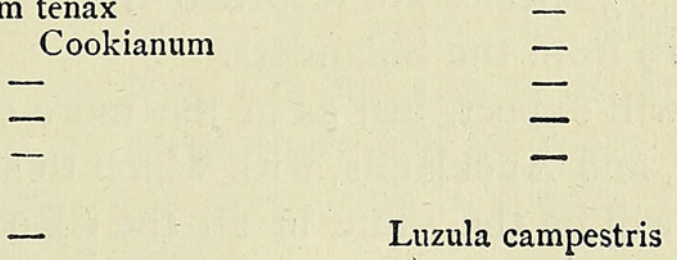

Leptocarpus simplex

Scirpus aucklandicus

Carpha alpina

Gahnia procera

Oreobolus pectinatus

Carex lucida trifida

Hierochloe redolens

Poa foliosa

Astoni

Myosotis albida

Veronica elliptica

Thelymitra uniflora

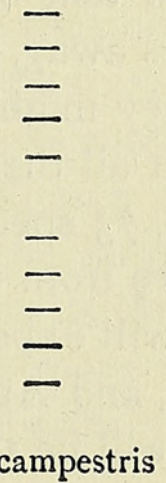

Carex trifida

Poa foliosa

Astoni

Dacrydium biforme

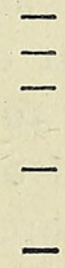


Long Island.

POLYPODIACEAE

Polystichum vestitum

Asplenium obtusatum scleroprium lucidum flaccidum bulbiferum

Blechnum durum capense

Histiopteris incisa Pteridium esculentum Polypodium diversifolium GLEICHENIACEAE Gleichenia circinata SCHIZAEACEAE Schizaea fistulosa LYCOPODIACEAE Lycopodium varium. ramulosum

TABLE I (continued).

Breakseas.

Polystichum vestitum Asplenium obtusatum scleroprium lucidum flaccidum

Blechnum durum capense

Histiopteris incisa

Polypodium diversifolium

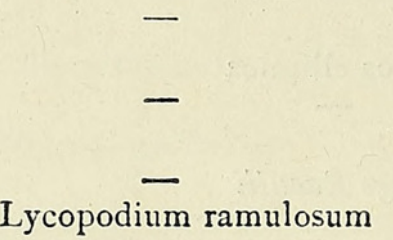

Solanders.

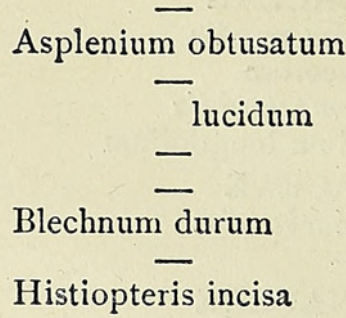

Asplenium obtusatum

二

It is clear, from the fact that these islands are separated from Stewart by some breadth of water, that they must have a very old flora, older on the whole than that of Stewart itself, especially the Solanders, which are over thirty miles away, but are a little nearer to the South Island of New Zealand (so that they might contain species not known in Stewart). We shall therefore expect all their floras to be small, especially that of the Solanders. In actual fact, 73 species are recorded from Long Island, 69 from the Breakseas, and 19 from the Solanders.

One will expect, just as in the more extended case of the Kermadecs, Chathams, and Aucklands, with which this may be compared, that much of the floras will be the same in all the islands. If we take the I 9 species of the Solanders, we find in fact that 16 of them also occur both in the Breakseas (on the other side of Stewart) and in Long Island, one occurs in Long Island only, and one in the Breakseas only. These two last quite probably occur in both these islands, but have not yet been recorded, and there remains only Senecio Stewartiae, which is also recorded for Herekopere Island in Foveaux Strait (as near the Solanders as Stewart itself) and the Snares.

Long and Breaksea islands have much larger floras, and we find on comparison that besides the 16 already mentioned which they have also in common with the Solanders, they have 29 in common between themselves only, making 45 in all. Long Island has 27 species not recorded from the Breakseas, and the Breakseas 23 not recorded from Long Island. These are printed in italics above. Glancing at the lists, it is fairly safe to say that about a dozen at least of those given for the Breakseas only, e. g. the orchids, ought certainly to be found also in Long Island, if it were examined at a different period of the year. On the whole, the resemblances between the floras of these three island groups are very striking. Poppelwell notes these resemblances, but puts them down to similarity of conditions, a cause which 
in the light thrown upon geographical distribution by age and area can no longer be accepted as sufficient to account for such phenomena.

Just as we found the flora of Stewart, as older, to be composed of the larger (in general, older) families and genera of New Zealand proper, so here we shall expect the flora of these islands to be composed of the larger families and genera of the Stewart flora, and that of the Solanders especially so. Testing this we find that of the New Zealand families 22 are above the average in size (in New Zealand) and 69 below. Of the former 2 I (95 per cent.) occur in Stewart, of the latter only $39(56$ per cent.) Of the Stewart families 15 are above the average (in Stewart) and 45 below. Of the former I 3 ( 86 per cent.) occur in the islets, of the latter 17 (37 per cent.). Of the islet families 9 are above the average and 21 below. Of the former 6 (66 per cent.) occur in the Solanders and of the latter 4 ( 19 per cent.) only. It is thus clear that on the average a family is represented everywhere in proportion to its size in the neighbouring country. We may put this in another way, thus. The average size in New Zealand and the surrounding islands of a family occurring there ( $91 \mathrm{fams} ., 1,392$ species) is 15 species. The average size in New Zealand of families occurring in Stewart is 21 species, or much higher. The average size in New Zealand of the families that occur in the islets now under consideration is 35 species ( 30 fams., I,059 species). And finally, the average size in New Zealand of the families occurring in the Solanders (II fams., 765 species) is 69 species. The figures thus form a progressive series, showing clearly that on the whole the larger in New Zealand a family is, the greater in the New Zealand area is its range.

We shall further expect that, as usual, there will be more families in proportion to genera, and more genera in proportion to species, the farther out we go from the centre of New Zealand.

TABLE II.

$\begin{array}{lccccc} & \text { Fams. } & \text { Gen. } & \text { Spp. } & \text { Gen. perfam. } & \text { Spp.pergen. } \\ \text { New Zealand } & 9 \text { I } & 329 & 1392 & 3 \cdot 6 & 4 \cdot 2 \\ \text { Stewart } & 60 & 169 & 383 & 2 \cdot 8 & 2 \cdot 2 \\ \text { Islets } & 30 & 56 & 98 & 1.8 & 1 \cdot 7 \\ \text { Solanders } & 11 & 13 & 15 & 1 \cdot I & \text { I.I }\end{array}$

The prediction is fully borne out.

As one goes outward from New Zealand in this way, the plants will on the average become steadily older, so that one will expect to find the proportion in common with the outlying islands (Kermadecs, Chathams, Aucklands), which also have old floras, steadily increasing. Testing this gives

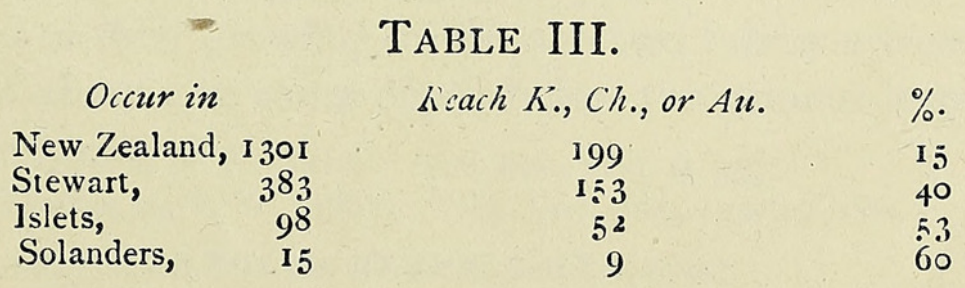


Again a steadily increasing percentage, bearing out the prediction.

Further, one will expect the proportion of wides, which on the whole are older, to increase relatively to that of endemics as one goes outwards from New Zealand to the Solanders.

\section{TABLE IV.}

$\begin{array}{lrc}\quad \text { Occur in } & \text { Wides. } & \text { Endemic }(N . Z \text {. and Isl.). } \\ \text { New Zealand } & \text { 30I or } 23 \% & \text { 1000 } \\ \text { Stewart } & \text { 129 or } 34 \% & 240 \\ \text { Islets } & 27 \text { or } 35 \% & 49 \\ \text { Solanders } & 6 \text { or } 40 \% & 9\end{array}$

If the ferns be included, the result is more clearly marked.

It is thus clear that for restricted areas like New Zealand and its neighbouring islands age and area can be relied upon to explain the general composition of any of the floras that occur; and in our next paper we shall go somewhat farther afield, endeavouring to trace the invasions of New Zealand from Indo-Malaya. 


\section{$2 \mathrm{BHL}$ Biodiversity Heritage Library}

Willis, J. C. 1919. "On the floras of certain islets outlying from Stewart Island (New Zealand)." Annals of botany 33, 479-484.

https://doi.org/10.1093/oxfordjournals.aob.a089738.

View This Item Online: https://www.biodiversitylibrary.org/item/235681

DOI: https://doi.org/10.1093/oxfordjournals.aob.a089738

Permalink: https://www.biodiversitylibrary.org/partpdf/320269

\section{Holding Institution}

Smithsonian Libraries

\section{Sponsored by}

Biodiversity Heritage Library

\section{Copyright \& Reuse}

Copyright Status: Not in copyright. The BHL knows of no copyright restrictions on this item.

This document was created from content at the Biodiversity Heritage Library, the world's largest open access digital library for biodiversity literature and archives. Visit BHL at https://www.biodiversitylibrary.org. 